\title{
HEPATITIS B AND C VIRUS INFECTIONS; IN HAEMODIALYSIS PATIENTS IN ABBOTTABAD, PAKISTAN
}

1. Assistant Professor, Department of Pathology,

Frontier Medical \& Dental College, Abbottabad.

2. Assistant Professor, Department of Medicine,

Frontier Medical \& Dental College Abbottabad.

3. Assistant Professor, Department of ENT,

Frontier Medical \& Dental College, Abbottabad.

4. Professor, Department of Pathology,

Frontier Medical \& Dental College Abbottabad.

Correspondence Address: Dr. Muhammad Safdar Khan, Assistant Professor, Department of Medicine,

Frontier Medical \& Dental College,

Abbottabad, Pakistan

safdaralula@gmail.com

Article received on:

07/07/2015

Accepted for publication:

00/00/2015

Received after proof reading:

$12 / 10 / 2015$

\author{
Dr. Muhammad Usman Anjum, Dr. Muhammad Safdar Khan², Dr. Nazar Muhamamd Afridi ${ }^{3}$, \\ Dr. Syed Humayun Shah ${ }^{4}$
}

ABSTRACT... Patients with end stage renal disease require haemodialysis as a part of their treatment. The incidence of hepatitis $B$ and $C$ virus infection is quite high in patients undergoing maintenance haemodialysis than in general population. This risk is specifically associated with use of blood and its products as well as repeated intravascular access in these patients. Objectives: To determine the seropositivity of hepatitis $B$ and $C$ virus infection in patients receiving haemodialysis. Design: Descriptive cross sectional study. Setting: Nephrology Department, Ayub Teaching Hospital, Abbottabad, Pakistan. Period: From October 2014 to April 2015. Methods: Five hundred patients were included in the study based on inclusion and exclusion criteria. Demographic data was recorded and detailed history was taken from each patient specifically about the no of blood transfusions received, the frequency of dialysis and the dialysis done in other centers. All patients were checked for the presence of hepatitis $B$ surface antigen ( $\mathrm{HbsAg}$ ) and antibodies to HCV using third generation enzyme linked immunoassay (ELISA). Results: Mean age of study sample was $46 \pm 5$ years with $60.8 \%$ males. Incidence of hepatitis positive cases was 164 (32.8\%), out of which 66 (13.2\%) patients were HBV positive and 98 (19.08\%) patients were HCV positive. The hepatitis B and C infections were more common in males than females. Seropositivity of HBV and HCV was higher (HBV $18.1 \%$ and HCV $22.2 \%$ ) among haemodialysis patients who have received more than three blood transfusions. The frequency of HBV and HCV infections increases significantly with the increase in frequency of dialysis, with 49 (17.11\%) patients were HBV positive and 70 (24.5 $\%$ patients were HCV positive cases, who have received haemodialysis for more than five times. There were 48 (15.7\%) HBV positive cases as well as 68 (22.3\%) HCV positive cases in patients who have received their treatment from a single center. Conclusion: Hepatitis $B$ and $\mathrm{C}$ infection is quite common in patients undergoing haemodialysis. The risk of these infections can be reduced by following infection control guidelines, proper training of the staff and strict screening of blood and blood products specifically for hepatitis $\mathrm{C}$ virus.

Key words: $\quad$ Haemodialysis, Hepatitis B virus, Hepatitis C virus, Pakistan

Article Citation: Anjum MU, Khan MS, Afridi NM, Shah SH. Hepatitis b and c virus infections; in haemodialysis patients in Abbottabad, Pakistan. Professional Med J 2015;22(10):1284-1288. DOI: 10.17957/TPMJ/15.3012

\section{INTRODUCTION}

Hepatitis $B$ virus (HBV) and hepatitis $C$ virus (HCV) infections are important cause of liver dysfunction worldwide. ${ }^{1}$ Their chronic infection can lead to major health problems especially liver cirrhosis and hepatocellular carcinoma. ${ }^{2}$ Prevalence of these infections varies among different centers throughout the world but it is high in haemodialysis patients as compared to the general population. ${ }^{3,4}$

Patients suffering from end stage renal disease (ESRD) require haemodialysis regularly as a part of renal replacement therapy. The number of patients who require haemodialysis was around
2.1 million worldwide, with an annual increase of 7 $\% .{ }^{5}$ The risk of acquiring HBV and HCV infections is quite high in patients receiving maintenance haemodialysis. This is due to exposure to blood and blood products, sharing or contamination of dialysis unit, breeches in following universal precautions and infection control protocols, repeated intravascular access and lack of training of staff conducting haemodialysis..$^{4-7}$

This study is conducted to determine the frequency of HBV and HCV infection in patients who are undergoing maintenance haemodialysis for ESRD. 


\section{MATERIALS \& METHODS}

This was a descriptive cross sectional study which was carried out in Nephrology Department of Ayub Teaching Hospital, Abbottabad, from October 2014 to April 2015.

After approval from Hospitals Ethics Committe, all the patients who presented for haemodialysis due to ESRD were included in the study. Patients requiring haemodialysis for other reasons like acute renal failure and patients receiving anti-viral therapy for HBV or HCV infection were excluded from the study. Based on inclusion and exclusion criteria, 500 patients were included in the study. Informed consent was taken, demographic data was recorded and detailed history was taken from each patient specifically about the no of blood transfusions received, the frequency of dialysis and whether haemodialysis was done in a single or multiple centers. All patients included in the study were checked for the presence of hepatitis $B$ surface antigen ( $\mathrm{HbsAg}$ ) and antibodies to $\mathrm{HCV}$ using third generation enzyme linked immunoassay (ELISA).

Haemodialysis was carried out with Bellco haemodialysis machines (Bellco, Italy), following a standard protocol. There were two dedicated haemodialysis units for hepatitis B \& C positive patients, specifically used for patients with ESRD and who were HBV or HCV positive.

The data collected in this study was recorded in a standardized proforma and analyzed using Statistical Package for Social Sciences (SPSS version 17). Categorical data e.g. gender, seropositivity for hepatitis was presented as frequencies and percentages while continuous data as mean and standard deviation.

\section{RESULTS}

There were 500 patients who were included in this study. Out of these, 304 patients were male (60.8 \%) and 196 (39.2\%) patients were female, as shown in Figure-l.3

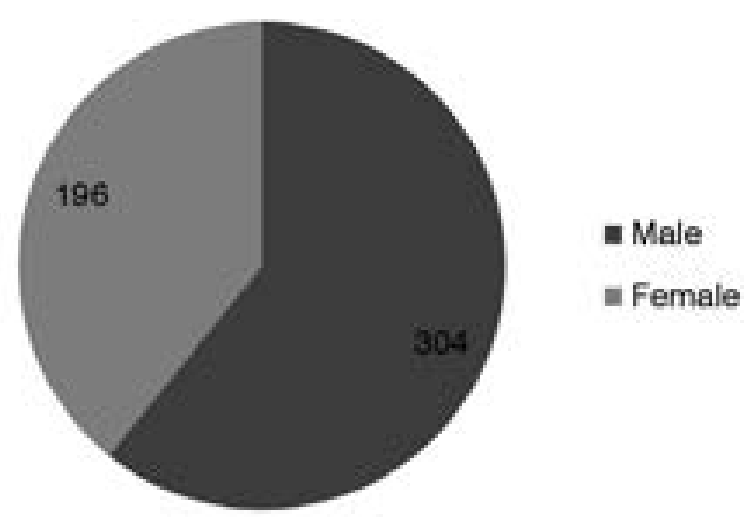

Figure-1. Gender-wise distribution of study sample

There were 164 (32.8\%) patients who were positive for HBV and HCV. Out of these 164 cases, $66(13.2 \%)$ patients were HBV positive and 98 (19.08\%) patients were HCV positive. As per the distribution of hepatitis positive patients according to the gender, among 304 male patents 45 (14.8 $\%)$ were HBV positive and 65 (21.3\%) were HCV positive, showing high predilection for male gender. Similarly, among 196 female patients, 21 (10.7\%) patients were HBV positive while 33 (16.8 $\%)$ were HCV positive, as shown in Table-I.

\begin{tabular}{|c|c|c|c|c|c|}
\hline Gender & $\begin{array}{c}\text { No. of patients, } \\
(\mathbf{n = 5 0 0 )}\end{array}$ & $\begin{array}{c}\text { HBV Positive Patients, } \\
(\mathbf{n = 6 6 )}\end{array}$ & Percentage & $\begin{array}{c}\text { HCV Positive } \\
\text { Patients, }(\mathbf{n = 9 8 )}\end{array}$ & Percentage \\
\hline Males & 304 & 45 & $14.8 \%$ & 65 & $21.3 \%$ \\
\hline Females & 196 & 21 & $10.7 \%$ & 33 & $16.8 \%$ \\
\hline Total & 500 & 66 & $13.2 \%$ & 98 & $19.08 \%$ \\
\hline
\end{tabular}

The mean age of study population was $46 \pm 5$ years. In HBV positive cases, the highest no of patients, 47 (17.6\%), were seen between the age of $30-60$ years followed by $12(8.2 \%)$ patients who were more than 60 years of age and 7 (8\%) patients were less than 30 years of age. Among
HCV positive patients, highest no of patients, 73 $(27.2 \%)$, were between the age of $30-60$ years followed by $10(11.4 \%)$ and $15(10.3 \%)$ in age group of less than 30 years and in age group of more than 60 years of age respectively, as shown in Table-II. 


\begin{tabular}{c|c|c|c|c|c|} 
Age & $\begin{array}{c}\text { No. of patients, } \\
(\mathbf{n = 5 0 0 )}\end{array}$ & $\begin{array}{c}\text { HBV Positive } \\
\text { Patients, (n=66) }\end{array}$ & Percentage & $\begin{array}{c}\text { HCV Positive } \\
\text { Patients, (n=98) }\end{array}$ & Percentage \\
\hline Upto 30 years & 87 & 7 & $8.0 \%$ & 10 & $11.4 \%$ \\
\hline 30-60 years & 268 & 47 & $17.6 \%$ & 73 & $27.2 \%$ \\
\hline > 60 years & 145 & 12 & $8.2 \%$ & 15 & $10.3 \%$ \\
\hline Total & 500 & 66 & $13.2 \%$ & 98 & $19.8 \%$ \\
\hline
\end{tabular}

With regards to the number of blood transfusions received the highest no of HBV and HCV positive cases were seen in the group who have received more than three blood transfusions. There were seven (11.6\%) HCV positive patients who have not received any blood transfusion, as shown in Table-III.

\begin{tabular}{|c|c|c|c|c|c|}
$\begin{array}{c}\text { No. of Blood } \\
\text { Transfusions }\end{array}$ & $\begin{array}{c}\text { No. of patients, } \\
(\mathbf{n = 5 0 0 )}\end{array}$ & $\begin{array}{c}\text { HBV Positive } \\
\text { Patients, (n=66) }\end{array}$ & Percentage & $\begin{array}{c}\text { HCV Positive } \\
\text { Patients, (n=98) }\end{array}$ & Percentage \\
\hline 0 & 60 & - & - & 7 & $11.6 \%$ \\
\hline$\leq 3$ & 175 & 18 & $10.2 \%$ & 32 & $18.2 \%$ \\
\hline T3 & 265 & 48 & $18.1 \%$ & 59 & $22.2 \%$ \\
\hline Total & 500 & 66 & $13.2 \%$ & 98 & $19.8 \%$ \\
\hline
\end{tabular}

Table-III. No of HBV \& HCV positive cases with regards to the no of blood transfusions received

There were 49 (17.11\%) HBV positive and 70 (24.5\%) HCV positive cases in patients who have received dialysis for more than five times as shown in Table-IV.

\begin{tabular}{|c|c|c|c|c|c|} 
No. of Dialysis & $\begin{array}{c}\text { No. of patients, } \\
(\mathbf{n = 5 0 0 )}\end{array}$ & $\begin{array}{c}\text { HBV Positive } \\
\text { Patients, (n=66) }\end{array}$ & Percentage & $\begin{array}{c}\text { HCV Positive } \\
\text { Patients, }\end{array}$ & Percentage \\
\hline$\leq 5$ & 215 & 17 & $7.9 \%$ & 28 & $13 \%$ \\
\hline$>5$ & 285 & 49 & $17.1 \%$ & 70 & $24.5 \%$ \\
\hline Total & 500 & 66 & $13.2 \%$ & 98 & $19.8 \%$ \\
\hline
\end{tabular}

Table-IV. No of HBV \& HCV positive cases with respect to the frequency of haemoialysis

The maximum no of HBV \& HCV positive cases were seen in single centre patients as compared to multi-centre. There were 48 (15.7\%) HBV positive cases as well as 68 (22.3 \%) HCV positive cases in patients who have received their treatment from single center, as shown in Table-V.

\begin{tabular}{|c|c|c|c|c|c|} 
Centre & $\begin{array}{c}\text { No. of patients, } \\
(\mathbf{n = 5 0 0 )}\end{array}$ & $\begin{array}{c}\text { HBV Positive } \\
\text { Patients, (n=66) }\end{array}$ & Percentage & $\begin{array}{c}\text { HCV Positive } \\
\text { Patients, (n=98) }\end{array}$ & Percentage \\
\hline Single centre & 304 & 48 & $15.7 \%$ & 68 & $22.3 \%$ \\
\hline Multiple centre & 196 & 18 & $9.8 \%$ & 30 & $15.3 \%$ \\
\hline Total & 500 & 66 & $13.2 \%$ & 98 & $19.8 \%$ \\
\hline
\end{tabular}

Table-V. No of HBV \& HCV positive cases with regards to the number of haemodialysis centers attended

\section{DISCUSSION}

This study was carried out to ascertain the frequency of hepatitis $B$ \& $C$ virus infection in ESRD patients who were undergoing haemodialysis.

Our study has shown that the mean age of patients was $46 \pm 5$ years and there is predominance of male gender $(60.8 \%)$. Batieha et al in their study conducted in Jordan have shown the same result where mean age of patients was $48.9 \pm 16.7$ years and the no of males was $55.9 \% .^{8}$ Similarly, a study done in Libya by Alashek et al have shown that the no of males was while $58 \%$ while the median age of patients was 49 years. ${ }^{2} \mathrm{HBV}$ and $\mathrm{HCV}$ infections were more prevalent in males in our study. 
Our study has shown that total 164 (32.8\%) patients were positive for HBV and HCV infection. Same results were reported by Alashek et al in their study conducted in Libya where the seropositivity for both HBV and HCV infection in haemodiaysis patients was reported to be 34.9 $\%{ }^{2}$ The number of HBV and HCV positive cases was 66 (13.2\%) and 98 (19.08\%) respectively, showing higher incidence of HCV infection than HBV infection. Similar results were also reported by other studies. A study done by Yakaryilmaz et al in a Turkish haemodialysis unit and another by Batieha et al in Jordan have also shown the prevalence of HCV infections to be $20.2 \%$ and $21 \%$ while that of HBV infection to be $13.3 \%$ and $4.0 \%$ respectively, which is comparable to our study. ${ }^{8,9}$ Mahmud et al, in their study done in Karachi, have reported the higher incidence of HCV infection in haemodialysis patients, which was $16.4 \% .^{10}$ A similar study conducted in Iran by Assarehzadegan et al has also shown the higher prevalence of $\mathrm{HCV}$ infections than the HBV infections. ${ }^{11}$

Our study has shown higher seropositivity of HBV (18.1\%) and HCV (22.2 \%) cases among haemodialysis patients who have received multiple blood transfusions. Blood transfusions itself constitute an important risk factor for acquisition of HBV and HCV infections. ${ }^{5}$ A study in Iran by Assarehzadegab et al and another one in Vietnam by Duong et al has also shown that the incidence of hepatitis $B$ and $C$ infection is quite high in haemodialysis patients receiving multiple blood transfusions. ${ }^{5,11}$ Blood transfusion is an integral part of management of patients suffering from ESRD. ${ }^{2}$ But, at the same time it poses significant threat of transmission of HBV and specifically of HCV. ${ }^{3,12}$ Therefore, strict blood screening practices must be ensured to minimize the spread of these infections.

It was found out in our study that the incidence of HBV and HCV infections increases considerably with the increase in frequency of dialysis. About $49(17.11 \%)$ patients were HBV positive and 70 (24.5\%) patients were HCV positive cases who have received dialysis for more than five times. This has also been reported by other studies. Duong et al have shown higher incidence of HCV in patients having multiple haemodialysis. ${ }^{5}$ This could be attributed to failure to follow infection control measures as well as contamination of components of a dialysis machines used for haemodialysis. ${ }^{6}$

The maximum no of HBV \& HCV positive cases were seen in patients who received their haemodialysis at a single centre. This is in contrast to what Alashek et al and Duong et al have reported in their studies. ${ }^{2,5}$ They have reported a higher incidence of HBV and HCV infection in patients receiving or have recieved haemodialysis from multiple centers. ${ }^{2,5}$ This discrepancy in results could be due to multiple reasons; failure to observe infection control measures properly, lack of properly trained staff and contamination of haemodialysis unit at a centre. ${ }^{6}$ Furthermore, breech in safety measures of one centre can lead to spread of HBV and HCV infection to others who were receiving their treatment at that center.

\section{CONCLUSION}

Hepatitis Band $C$ virus infections are quite common in patients with ESRD who are undergoing maintenance haemodiaysis. Therefore, measures should be taken to reduce the transmission of these viruses among these patients. This could be done by following universal precautions and infection control practices, proper training of staff in these units as well as strict screening of blood and blood products for HBC and HCV.

Copyright(C) 27 July, 2015.

\section{REFERENCES}

1. Anjum MU, Khan F, Ali N, Khan S, Shah SH. Seroprevalence of Hepatitis B \& C and Pattern of Liver Function Tests in Hepatitis Positive Patients in Abbottabad. Scholars Journal of Applied Medical Sciences. 2015;3(2F):953-6.

2. Alashek WA, Mclntyre CW, Taal MW. Hepatitis B and $C$ infection in haemodialysis patients in Libya: prevalence, incidence and risk factors. BMC Infectious Diseases. 2012;12:265-72.

3. Jasuja S, Gupta AK, Choudhry R, Kher V, Aggarwal DK, Mishra A, et al. Prevalence and associations of 
hepatitis C viremia in hemodialysis patients at a tertiary care hospital. Indian Journal of Nephrology. 2009;19(2):62-7.

4. Idrees MK, Batool S, Ahmed E. Hepatitis B virus among maintainence haemodialysis patients: A report from Karachi, Pakistan. Journal of Pakistan Medical Association. 2011;61(12):1210-4.

5. Duong CM, Olszyna DP, McLaws ML. Hepatitis B and C virus infections among patients with end stage renal disease in a low-resourced hemodialysis center in Vietnam: a cross-sectional study. BMC Public Health. 2015;15:192-8.

6. Savey A, Simon F, Izopet J, Lepoutre A, Fabry J, Desenclos JC. A large nosocomial outbreak of hepatitis $C$ virus infections at a hemodialysis center. Infection Control and Hospital Epidemiology. 2005;26(9):752-60.

7. Cendoroglo Neto $M$, Draibe $S A$, Silva $A E$, Ferraz ML, Granato $C$, Pereira $C A$, et al. Incidence of and risk factors for hepatitis B virus and hepatitis C virus infection among haemodialysis and CAPD patients: evidence for environmental transmission. Nephrology Dialysis Transplantation. 1995;10(2):240-6.

8. Batieha A, Abdallah S, Maghaireh M, Awad Z, Al-
Akash N, Batieneh A, et al. Epidemiology and cost of haemodialysis in Jordan. Eastern Mediterranean Health Journal. 2007;13(3):654-63.

9. Yakaryilmaz F, Gurbuz OA, Guliter S, Mert A, Songur Y, Karakan T, et al. Prevalence of occult hepatitis B and hepatitis $\mathbf{C}$ virus infections in Turkish hemodialysis patients. Renal Failure. 2006;28(8):729-35.

10. Mahmud HM, Siddiqui M, Bashir B, Ali SF, Baloch AA, Masroor M. Hemodialysis patients profile at Dow University of Health Sciences, Karachi. Pakistan. Pakistan Journal of Medical Sciences. 2014;30(6):132730.

11. Assarehzadegan MA, Shakerinejad G, Noroozkohnejad R, Amini A, Rahim Rezaee SA. Prevalence of hepatitis $C$ and $B$ infection and HCV genotypes among hemodialysis patients in Khuzestan province, southwest Iran. Saudi Journal of Kidney Diseases and Transplantation. 2009;20(4):681-4.

12. Méndez-Sánchez N, Motola-Kuba D, Chavez-Tapia NC, Bahena J, Correa-Rotter R, Uribe M. Prevalence of Hepatitis C Virus Infection among Hemodialysis Patients at a Tertiary-Care Hospital in Mexico City, Mexico. Journal of Clinical Microbiology. 2004;42(9):4321-2.

\section{PREVIOUS RELATED STUDY}

Shabnam Naseer Awan, Shazia Nayyar, Nadeem Ashraf. OBSTETRICS AND PERINATAL OUTCOME; RISK FACTORS FOR HEPATITIS B AND C TRANSMISSION (Original) Prof Med Jour 13(4) 511-516 Oct, Nov, Dec, 2006.

Shahnaz Anwar, Sheikh Atiq-ur-Rehman, Muhammad Younis Khan. RISK FACTORS; COMPARISON IN HEPATITIS B AND C CARRIER PREGNANT WOMEN \& HEALTH PREGNANT WOMEN. (Original) Prof Med Jour 16(4) 518-525 Oct, Nov, Dec 2009.

\begin{tabular}{|c|c|c|c|}
\hline \multicolumn{4}{|c|}{ AUTHORSHIP AND CONTRIBUTION DECLARATION } \\
\hline Sr. \# & Author-s Full Name & Contribution to the paper & Author $=\mathbf{s}$ Signature \\
\hline 1 & & $\begin{array}{l}\text { Performed study \& written } \\
\text { manuscript }\end{array}$ & \\
\hline 2 & Dr. Muhammad Safdar Khan & Performed study/co-author & \\
\hline 3 & Dr. Nazar Muhammad Afridi & Performed study/co-author & \\
\hline 4 & Dr. Syed Humayun Shah & $\begin{array}{l}\text { Conceived the idea, } \\
\text { Supervised \& proof read } \\
\text { the manuscript }\end{array}$ & 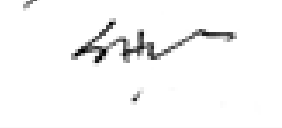 \\
\hline
\end{tabular}

